tic Atlas were published. Since 2011, Czech dialectologists have been working on the Dictionary of Czech Dialects. The dictionary is being created in a special computer programme. It captures the dialect lexicon in Bohemia, Moravia and Silesia over the past ca. 150 years. An electronic version of the Dictionary has been available since 2016. The Department of Dialectology is a team member of The Slavic Linguistic Atlas project. The $9^{\text {th }}$ volume "Reflexes *tort, *tolt, *tert, *telt, *ort, *olt” was published by Czech dialectologists in 2019 .

DOI: $10.31168 / 0459-6.24$

А. Панчевска (Скопје, Северна Македонија)

\title{
Називите за 'кукла' во македонските дијалекти во поширок словенски контекст (според материјалите на ОЛА)
}

\section{Вовед}

Во овој текст ќе биде обработен материјалот од прашањето од Х Лексички том на «Општословенскиот лингвистички атлас» (ОЛА 10) од областа на народните обичаи. Станува збор за називите на 'кукла' во словенските дијалекти, т. е. во пунктовите опфатени во ОЛА - 853 населени места од целата словенска територија. Македонскиот дијалектен комплекс во овој проект е претставен со 24 населени места кои се распоредени во рамките на државните граници, но и надвор од нив. Едно населено место се наоѓа во Република Албанија, а 8 во Република Грција. Називите за кукла се предмет на обработка на прашањето L 2291 'кукла' според Прашалникот на ОЛА, а се обработени во картата бр. 35 во Х лексички том на ОЛА (ОЛА 10: 158).

Овие називи на целата словенска територија означуваат предмет, фбигура, обично женска, што служи како детска 
играчка. Куклата е модел на човечко суштество, а најчесто се користи како играчка за деца. Традиционално, овие предмети се користеле при магиски и верски обреди во целиот свет, па и кај Словените. «Трагите на оваа варијанта од веригата на траењето особено се присутни во кругот на пролетните ритуали, кои го одразуваат доаѓањето на новата година, поточно новиот плоден циклус на годината. Тие во основа, се идентични кај сите индоевропски народи. Според досегашните сознанија, словенските примери се карактеристични по тоа што во некои подрачја се заувани во мошне изворна форма. Основниот елемент во нив е обредната женска фригура - кукла, изработена од разни растителни елементи (гранки, лисја, кора, трева, слама, цветови...)» (Чаусидис 1994: 237). Традиционални кукли изработени од материјали како што се глина и дрво се наоѓаат во Америка, Азија, Африка и Европа. Најраните документирани кукли потекнуваат од древните цивилизации на Египет, Грција и Рим. Тие се изработени како сурови, рудиментирани играчки, а на некој начин претставуваат и уметнички израз.

На македонската јазична територија се појавуваат четири називи за именување на овој предмет. Пошироко, на словенската територија, се употребуваат повеке други. Овде ке ги разгледаме македонските називи, но и оние на останатата словенска територија, за да се согледа местото на македонските говори во поглед на овој назив во поширокиот словенски јазичен свет. Ке бидат разгледани етимолошки, но и во поглед на семантичката мотивација, за да се најдат евентуалните нишки на поврзување при изведувањето на овие називи.

\section{Географска дистрибуција}

Во продолжение ќе бидат наведени литературните називи во сите словенски јазици: словенечки - punčka, српски лутка, хрватски - lutka, македонски - кукла, бугарски - 
кукла, чешки - panna, panenka, словачки - bába, лужички - pupka, полски - lalka, белоруски - лялька, украински - лялька, руски - кукла.

а. Географрска дистрибуција на називите во македонските пунктови:

90 - kukła, 92-93 - kukła, 94 - kukła, łazarka, 95-97 kukła, 98 - 'kukła, 99 - kukła, igračka, 100-101 - kukła, 102-105 - 'kukła, 106 -/, 107 —'nuska, 108 - 'kukła, 109-/, 110-111 - 'kukła, 112 -/, 113-113a - 'kukła.

Од материјалот може да се забележи дека доминантно се употребува називот кукла, но се јавуваат три други поеднинечни називи - лазарка, играчка и нуска. На пошироката словенска територија се употребуваат уште неколку називи, а може да се забележи и дека некои од нив се всушност заемки.

б. Географска дистрибуција на називите во другите словенски дијалекти.

На руската дијалектна територија доминантна е формата kukla, а во неколку пункта се срекава и lalka; на украинската територија се употребуваат главно две форми lalka и kukla, а ограничено се среќават babka и babouka; на белоруската исто така се употребуваат двете форми lalka и kukla; на полската територија доминира формата lalka, а се среќаваат и pupka, pupa, točka, dete, pana; на лужичката територија се јавуваат две форми - рорка во еден пункт, а во останатите 3 рира; на словачката во употреба се повеќе фpopми: paniča, panenka, pana, baba, bapka, babika, popka, lalka; на чешката територија главно во употреба е формата pana / panenka, а во неколку пункта и lalka; на словенечката се употребуваат исто така повеќе фрорми: pupa, bambola, punca, punčka, lutka, beba, bebica, baba, puža; на хрватската во употреба се неколку фрорми: рupa, beba, bebica, lutka; босанската: lutka, поретко и beba; српската: lutka и поретко popica; и на бугарската дијалектна територија: kukla, а во еден пункт и pipl'a. 


\section{Етимолошка анализа}

а. кукла

Најчесто употребуван назив за именување на оваа играчка во македонските говори е кукла. Се јавува на целата јазична територија, само во еден пункт има друг назив. Овој назив, кој всушност е заемка, се смета дека е добиен од латинскиот, но преку грчкиот. Сп.: «Через ср.-греч., нов.-греч. койкла (то же) из лат. cuculla; <..> Невероятно посредничество тур. kukla <..> Абсолютно неприемлемо предположение об исконнослав. происхождении и родстве с ку́ка 'кулак', ку́киш...» (Фасмер II: 405). Сп. и во «Бугарскиот етимолош-

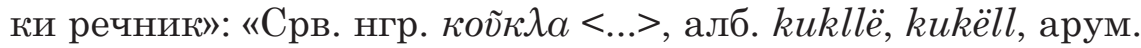
cúclă 'кукла', тур. kukla. Обикновено се смята за заето от нгр.

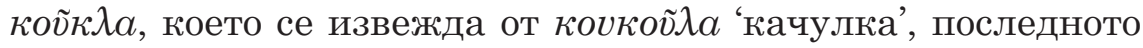
от лат. cuculla 'качулка', което можеби е от келтско kukka 'връх'...» (БЕР III: 91). Сп. понатаму: "Cucullus, -і̄ m. : capuchon; cornet de papier <...> Sans doute mot d'emprunt, illyrien ou gaulois. Cf. le nom du dieu gaulois Cucullātus...» (Ernout, Meillet 2001: 154). Значи последниве автори сметаат дека потеклото на зборот е веројатно илирско или пак галско. Понатаму, според нив, овој збор од латинскиот се пренел во повеќе други јазици, меѓу кои и во грчкиот, коvкой $\imath$.

Освен во македонските говори се среќава и во бугарските, но и на исток во руските, украинските и во белоруските. Во рускиот јазик тоа е и литературниот назив за овој вид играчка.

\section{б. лазарка}

Во еден пункт се среќава специфричен назив за оваа играчка, «позајмен» од народната традиција. Во македонскиот јазик лазарка е девојка што пее и таниува на Лазарова сабота. Станува збор за еден од поголемите христијански празници од пролетниот циклус. Се прославува на тој начин што во раните утрински часови групи девојчиња облечени во традиционална невестинска облека одат низ населените 
места и пеат т. н. лазарски песни, кои обично се со духовита содржина и се со желби за здравје, успех и напредок.

Ваков тип на назив не се среќва во ниту еден друг говор.

\section{в. играчка}

Во еден пункт како одговор на ова прашање, покрај кукла, се појавува називот играчка, којшто е генерички, општ назив за предмет што служи за играње на деца, за забава. Се изведува од глаголот игра 'се занимава, се забавува на некаков начин, со нешто, со некаква игра'.

г. нуска

Последниот назив кој се јавува на македонската дијалектна територија, нуска, е всушност заемка од албанскиот. Албанскиот збор е пusё и е со значење 'невеста, млада жена, млада снаа'. Сп. во продолжение: «Borrowed from Rom *nūptia, a local variant of Lat nūpta 'married woman, wife, bride'; Camarda I 52 (links nuse to the continuants of IE *snusos 'daughter-in-law'...)»(Orel 1998: 302-303). Повторно станува збор за изведување на називот поврзано со поимот млада девојка.

Во другите јужнословенски јазици доста често се употребува називот lutka. Се изведува од прасловенското *lqtz, со значење 'кукла, марионета'. Овој облик се поклопува со староруското lutzkz 'играч' и тоа било неговото првобитно значење. Според тоа, во старословенскиот таа била именка која означува дејство (nomina actionis) со значење 'играч кој нешто прикажува' (Skok II: 333).

Покрај lutka, во јужнословенските јазици (освен во српскиот, македонскиот и бугарскиот) се употребува и називот beba или деминутивното bebica. Овој назив всушност се однесува на именување на мало дете, новороденче, но во одредени случаи може да служи и за именување на овој тип на играчка. Сп. кај (Skok I: 128-129).

Интересно е дека во словенечките и словачките пунктови за оваа играчка се употребува називот baba. Во словенските 
јазици оваа лексема означува стара жена, оттука е интересен фрактот дека се употребува за именување играчка за деца, која обично се изведува од називи за девојка, девојче. Инаку претставува ономатопејска редупликација од детскиот јазик и е во прасродство со лит. bóba, латв. bãba. (Bezlaj I: 7; Skok I: 82-83). Потврда за тоа дека овој назив се употребува за именување на овој тип играчка за деца наоѓаме кај Machek (Machek 1968: 40).

Во словенечките пунктови се јавува називот punčka. Овој назив, punca, punčka, е изведен од италијанското pulcella, кое значи девојка, добиено на основа на латинското pullus 'потомство' (Bezlaj III: 136).

Еден од најчесто употребуваните називи за оваа играчка во западните словенски јазици е lalka, деминутивна форма од lala. Има значење на детска играчка со линијатурен, налален човечки облик. Во полскиот јазик се забележува од XVIII век, а потеклото му е од детскиот јазик, со редупликација, слична на останатите називи baba, mama, tata. (Boryśs 2008: 279-280). Ваквата појава на изведување називи со редупликација на слогови е позната и во другите јазици.

Во говорите на западнословенските јазици често се употребува називот pana, panenka. Првото значење на оваа лексема е ллада, нелажена девојка. Потекнува од прасловенското *gъpanьnz со значење 'ќерка на господин, pan' (Borý́s 2008: 411).

Во полските говори се употребуваат уште два називи, dete и točka, како одговори во еден, односно два пункта. Првиот назив, dete, се јавува и во еден руски пункт. Етимолошки е разбирлив, но фонетската реализација е невообичаена за полскиот јазик. За вториот назив, toč $k a$, не најдовме соодветна етимолошка интерпретација.

Следните називи кои се употребуваат на словенската јазична територија всушност претставуваат заемки од други јазици. 
Од германското Рирре, кое означува кукла, се изведуваат формите рира и рирkа. Првата се употребува во словенечките говори, во хрватските, лужичките и во полските. Втората е застапена во еден словенечки пункт, во еден лужички и во неколку полски пункта.

Исто така од германското Рорре, дијалектно, исто со значење кукла, се добиваат називи во српскиот, popica, и во полскиот, рорkа.

Во три пункта на украинската дијалектна територија се употребува називот babouka, по потекло заемка од унгарското bábuka, со значење кукла (Dankovszky 1833: 85-86).

Заемка од италијанскиот е називот bambola, кој се употребува во три пункта на словенечката јазична територија. Италијанскиот назив е исто bàmbola и потекнува од називот за деme, bambino 'uomo prima degli otto anni, cioè prima che sia ragazzo', кое пак е добиено од старото bambo ‘будала' (Prati 1951: 97-98).

Исто така во три словенечки пункта се употребува називот риг̆а. Тој претставува заемка од латинскиот, конкретно од pūsa 'мала девојка, девојче', «Pūsus, -і̄ m.; pūsa, -ae f. : garcon, fille...» (Ernout, Meillet 2001: 547).

\section{Заклучок}

На прв поглед од кратката анализа може да се стекне впечаток дека голем дел од називите за овој тип детска играчка во словенските јазици, говори, се изведуваат врз основа на заемки од други јазици. Разбирливо, тоа се случува најчесто од јазици со кои говорите се во контакт. За употребата на заемките најверојатно придонесува фрактот дека овој тип на играчки се од поново време, т. е. некаде од 15-от век. Во некои култури каде што куклите се користеле во обредни ритуали, се сметало дека се под влијание на магични сили и не им се давале на децата да си играат со нив. Се смета дека модерната кукла, која служи примарно како 
детска играчка, своите корени ги има во Германија токму во тој период, 15-от век. Со индустријализацијата, како и со појавата на новите материјали како што се порцелан и пластика, куклите почнуваат масовно да се произведуваат. Денеска, може да се каже дека претставуваат основен тип на детска играчка.

Па така, во редот на заемките спаѓаат повеќе називи. Еден од најфреквентно употребуваните називи не само во македонскиот, kukla, е изведен од заемка од латинскиот, но во словенските јазици најверојатно стигнал преку грчкиот. И уште еден назив од македонските говори, nuska, е изведен од заемка од албанскиот. Освен нив, називи изведени од заемки се и punčka, од италијанскиот, преку романскиот, pupa, pupka// popka, popica од германскиот, babouka од унгарскиот, bambola од италијанскиот и puža од латинскиот. Останатите називи кои се сеќваат во словенските говори се од словенско потекло - општиот назив играчка; може да се каже дека тука спаѓа и специфичниот назив од македонските дијалекти - лазарка; потоа lutka, beba/bebica, baba, lalka, pana / panenka, dete. Како што може да се забележи, во словенските јазици нема специјализиран израз од словенско потекло за кукла, освен можеби lutka и lalka, останатите називи се всушност првобитно називи за дете, девојче, бебе, па дури и баба.

Со оглед на тоа што, пак, оваа играчка претставува модел на човек, најчесто млада жена, девојка, не зачудува ниту фрактот дека именувањето го добива по некоја таква лексема, најчесто девојка, девојче. Во најголем дел од називите таков е случајот. Исклучок претставуваат називите kukla, што значи капа, капаче, конус од хартuја; igračka (од глаголот игра); може да се каже дека тука спаѓа и називот lutka, кој првобитно се однесува на играч кој нешто прикажува. Интересен е називот baba/bapka/ babika бидејќи е единствениот од сите што е изведен од лексема што означува стара 
жена, за разлика од останатите кои се однесуваат на млади девојки, девојчиња.

Според изборот на називи за именување на оваа детска играчка македонскиот јазик, односно неговите говори, во овој случај се одделуваат од останатите јужнословенски јазици, освен бугарскиот, бидејки не употребуваат ниту еден назив кој таму е застапен. Преку називот кукла, како најдоминантен во употребата, македонскиот се доближува до источнословенските јазици. Но, со останатите три називи, иако единечни, тој повторно покажува и своја специфика, посебно со називот лазарка кој претставува уникатен начин на изведување назив за оваа детска играчка.

\section{Литература}

БЕР - Български етимологичен речник, III, 1986, ред. В. И. Георгиев. София: БАН.

ОЛА 10 - Общеславянский лингвистический атлас. Серия лексико-словообразовательная. Вып. 10. Народные обычаи / отв. ред. Т. И. Вендина. М.; СПб.: Нестор-История, 2015.

Фасмер II - Фаслер М. Этимологический словарь русского языка. М.: Прогресс, 1986. Т. 2.

Чаусидис 1994 - Чаусидис H. Митските слики на јужните словени. Скопје: Мисла, 1994.

Bezlaj I - Bezlaj F. Etimološki slovar slovenskega jezika. 1. Ljubljana: SAZU, 1977.

Bezlaj III - Bezlaj F. Etimološki slovar slovenskega jezika. 3. Ljubljana: SAZU, 1995.

Boryś 2008 - Boryś W. Słownik etymologiczny języka polskiego. Krakow: Wydawnictwo Literackie, 2008.

Dankovszky 1833 - Dankovszky G. Magyaricae linguae. Lexicon criticoetymologicum. Pressburg: Belnay, 1833.

Ernout, Meillet 2001 - Ernout A., Meillet A. Dictionnaire étymologique de la langue latine. Histoire des mots. Paris: Klincksieck, 2001.

Machek 1968 - Machek V. Etymologický slovník jazyka českého a slovenského. Praha: Československá akademie věd, 1968.

Orel 1998 - Orel V. Albanian etymological dictionary. Leiden; Boston; Köln: Brill, 1998. 
Prati 1951 - Prati A. Vocabolario etimologico italiano. Torino: Garzanti, 1951.

Skok I - Skok P. Etimologijski rječnik hrvatskoga ili srpskoga jezika. Knj. 1. Zagreb: JAZU, 1971.

Skok II - Skok P. Etimologijski rječnik hrvatskoga ili srpskoga jezika. Knj. 2. Zagreb: JAZU, 1972.

\section{The Names for 'doll' in the Macedonian Dialects in a Wider Slavic Context (according to OLA materials)}

The text discusses the names for 'doll, puppet' in the Macedonian dialects and their etymology, as well as the motivations for their derivation. This analysis provides an insight into the place of the Macedonian dialects in relation to this issue in the wider Slavic context. The name kukla, which is most widespread on the Macedonian dialect territory, connects the Macedonian dialects with the other East Slavic languages. Many of the names used in dialects, such as kukla, are borrowings from other languages. Those of Slavic origin, as well as borrowings, are basically derived from lexemes denoting a young girl. For this analysis, the dialect material from the Slavic Linguistic Atlas (OLA) is used, in which the Macedonian dialect territory is represented with 24 villages.

DOI: $10.31168 / 0459-6.25$

\section{Н. Е. Ананьева (Москва, Россия) \\ К вопросу о польских островных говорах}

1. Островки (анклавы) польских диалектных идиомов разбросаны на значительной территории бывшего СССР. Традиционно о таких островных диалектах говорят по отношению к образованиям, оторванным от «материнской» территории и фрункционирующим на новой для них терри- 